\section{Más alumnos, más facultades. ¿El desorden traerá algo de luz?}

José M. Peinado Herreros

El curso académico que ahora termina ha sido uno de los más intensos que han vivido en los últimos tiempos las facultades de medicina españolas. La titulación, sin buscarlo, ha protagonizado un debate en el que se han mezclado intereses políticos, cambios legislativos, inmovilismo universitario, problemas asistenciales y un largo etcétera presidido por el desorden y, en gran medida, la improvisación tan propia de nuestro país ${ }^{1}$. En apenas cuatro años, el Sistema Nacional de Salud ha pasado del paro y exceso de médicos a una demanda de profesionales imposible de satisfacer con racionalidad. Veamos cómo se llega a esta situación.

El inicio de la formación especializada vía médico interno residente (MIR), junto con un excesivo número de licenciados, supuso para nuestro país, a final de los años setenta, un cambio en la estructura de la profesión hasta entonces desconocido. Sólo unos pocos accedían a la formación especializada. El resto, asimilado a un 'cierto' segundo nivel, buscó un hueco laboral básicamente en la atención primaria, en las zonas rurales y en las bolsas del paro ${ }^{2}$. Además, en 1995 se aplica la directiva europea sobre libre circulación de profe-

'Es difícil hacer una política sanitaria sensata sin tener un registro fiable de datos de especialistas.' D. Marcos Peña, director general, Ministerio de Sanidad y Consumo, 1992.

'La adecuada planificación de los recursos humanos del Sistema Nacional de Salud es un elemento fundamental para garantizar una asistencia sanitaria de calidad. El grupo de trabajo que está abordando esta cuestión ha realizado notables avances, entre los que destacaría la necesidad de instrumentar un registro de profesionales sanitarios. Este registro nos permitirá a las administraciones sanitarias dotarnos de un instrumento clave para la ordenación de recursos, que se complementará con el estudio de necesidades de especialistas que se está elaborando.' D. ${ }^{a}$ Elena Salgado, ministra de Sanidad, 13 de septiembre de 2006.

2. En numerosas ocasiones actuaron como médicos especialistas, aunque sin título, lo que más tarde originó otra situación paradójica a la que hubo que poner remedio: los MESTOS.

\section{More students, more faculties. Will any light come from this turmoil?}

The academic year that is now ending has been one of the most intense experienced by Spanish Faculties of Medicine in recent years. The degree course has unwillingly been the subject of a debate that has involved an array of political interests, legislative changes, stagnation of the universities, welfare problems and a long list of other issues dominated by disorder and, to a great extent, the improvisation that is so characteristic of our country ${ }^{1}$. In just 4 years the national health system has gone from unemployment and a surplus of doctors to a demand for professionals that is impossible to meet in a rational manner. Let's see how we reached this situation.

The introduction of specialised training by means of the MIR (Medical Resident Intern), together with an excessive number of graduates, led to an unprecedented change in the structure of the profession in our country in the late 70 s. Only a few graduates were admitted to specialised training. The others, who were seen as a kind of second level, mainly sought jobs in primary care, in rural areas and on the vacancies lists at the unemployment office ${ }^{2}$. Furthermore, in 1995 the European Directive regarding the free movement of professionals was applied, which made it impossible to practise the profession without a specialist qualifica-

'It is difficult to implement a sensible health care policy without having a reliable register of data about specialists.' Mr. Marcos Peña. DirectorGeneral. Spanish Ministry of Health and Consumer Affairs. 1992

'Proper planning of human resources in the National Health System is a fundamental element to ensure high quality health care. The working group that is addressing this issue has made considerable progress, perhaps the most important example of which is the need to implement a register of health care professionals. This register will provide the Health care authorities with a key instrument for allocating resources, and this will be complemented with the study of specialists' needs that is being drawn up.' Ms. Elena Salgado. Spanish Minister of Health. $13^{\text {th }}$ September 2006

2 They often acted as specialists, although they were not qualified to do so, which later gave rise to another paradoxical situation that had to be resolved: the MESTOS (Specialised Physicians without Official Qualifications).
Ex decano de la

Facultad de Medicina. Universidad de Granada

E-mail

jpeinado@ugr.es 
sionales, que imposibilita ejercer la profesión sin título de especialista. Surge así el movimiento del $6=0$ ante la insuficiente oferta de plazas MIR, que se mantendrá hasta principios del nuevo siglo ${ }^{3}$.

A comienzos de 2002, se realizan las transferencias sanitarias a las últimas 10 comunidades autónomas. En todas se completan carteras de servicios y se potencia la construcción de nuevos centros de salud y hospitales. Nuestro país vive momentos de gran desarrollo económico. La población envejece, pero a la vez crece por la inmigración en más de cinco millones de habitantes. La sanidad privada experimenta un gran crecimiento. En poco tiempo se toman otras dos decisiones, que en boca de nuestros políticos 'no mermarían la calidad asistencial': se jubila a los médicos mayores de 65 años en la mitad del país, y se amplia el MIR de familia a cuatro años ${ }^{4}$. No obstante, a pesar del subempleo y la precariedad en los contratos, todavía no hay señales de alarma ${ }^{5}$.

Hace apenas cuatro años comienzan a detectarse, con carácter general, déficit para cubrir bajas laborales y vacaciones. A pesar de que el número de médicos en España, en relación con su población, es uno de los más altos de la Organización para la Cooperación y el Desarrollo Económicos (OCDE), se comienza a hablar de falta de profesionales. Esta situación, hábilmente manejada en los medios, lleva al convencimiento progresivo de que nuestro país necesita más médicos. Las alarmas saltan definitivamente cuando en la convocatoria MIR 2006-07 quedan sin ocupar 87 plazas, de las cuales 54 son de medicina de familia, a pesar de que la oferta es de 5.946 y el número de candidatos es de $9.579^{6}$.

¿Cuál ha sido en este contexto el papel de las facultades de medicina? Durante casi 15 años

3. En el año 2000, siendo ministro de Sanidad Romay Beccaria, se producen manifestaciones estudiantiles en toda España exigiendo una mayor oferta de plazas MIR.

4. La aplicación del estatuto marco se produjo en Andalucía, Aragón, Asturias, Cantabria, Cataluña, La Rioja y Valencia. En 2008, en torno a 1.500 médicos no se podrán incorporar al mercado de trabajo. Algunos gestores, ahora, postulan su incorporación profesional sui generis tras el tercer año, sin finalizar la residencia. ¿Sic?

5. Sólo la fundación CESM analizó en 1999 el número de médicos en España.

6. En esta convocatoria, 2007-08, el número de plazas no ocupadas ha sido aún mayor, 253, de las cuales 189 han sido de medicina de familia y una de medicina preventiva. El resto, como el año anterior, de escuelas. La oferta de plazas ha sido de 6.388 para 10.564 candidatos. Todo esto refleja, a mi juicio, dos aspectos. De una parte, hay una gran recirculación de residentes en el sistema. De otra, son muchos los candidatos que renuncian a elegir ante la posibilidad de volver a realizar el examen al siguiente año. tion. And thus, given the insufficient offer of places to do the MIR, the $6=0$ movement came into being and was to continue until the dawn of the new century ${ }^{3}$.

In early 2002, the responsibility for public health care services was transferred from the central government to the last 10 Autonomous Communities. The portfolios of services were completed in all of these regions and construction of new health centres and hospitals was stepped up. Our country was undergoing a period of great economic development. The population was ageing, but at the same time it had grown due to the arrival of over five million immigrants. Private health care services were growing at a spectacular rate. In a short space of time, two other decisions were taken that, according to our politicians, 'would not reduce the quality of our health services': physicians over the age of 65 were pensioned off in half the country, and the Family Resident (MIR-F) now had to be completed in 4 years ${ }^{4}$. Nevertheless, despite underemployment and the precarious situation with regard to work contracts, there were still no warning signals going off ${ }^{5}$.

Generally speaking, the first difficulties to fill vacancies due to sick leave and holidays only began to be noticed four years ago. Although the number of doctors in Spain is one of the highest in the OECD, in relation to its population, we began to hear talk of a shortage of professionals. This situation, which was skilfully handled by the media, was gradually leading to the idea that our country needed more physicians. The alarms finally went off when the 2006-07 call for applications to the MIR left 87 places without candidates, of which 54 were for family medicine, although 5946 places were on offer and there were 9579 candidates $^{6}$.

In this context, what has been the role played by the Faculties of Medicine? For almost 15 years the number of newly-admitted students at the 28 Facul-

3 In the year 2000, while Romay Beccaria was Minister of Health, student demonstrations and protests took place all over Spain calling for a larger number of places on the MIR.

4 The Regulatory Framework was applied in Andalusia, Aragon, Asturias, Cantabria, Catalonia, La Rioja and Valencia. In 2008, about 1500 physicians will be unable to join the job market. Some authorities now consider the possibility of their being able to take up a job 'sui generis' following the third year, without finishing the residency. [sic ?].

5 Only the CESM Foundation analysed the number of physicians in Spain in 1999.

6 In this call for applications, 2007-08, the number of places left without candidates has been even higher, 253, of which 189 were for family medicine and 1 for Preventive medicine. The rest, as in the previous year were for schools. The number of places on offer was 6388 for 10564 candidates. In my opinion, all this reflects two points: On the one hand, there is a large amount of recirculation among residents in the system. On the other hand, many of the candidates choose not to do the exam again the following year. 
el número de alumnos de nuevo acceso a las 28 facultades de medicina se había estabilizado en torno a $4.400^{7}$. Si consideramos los estándares europeos, nuestro país cumplía con perfección la mágica cifra de un alumno por cada 10.000 habitantes. De hecho, el mantenimiento del número de alumnos ha permitido a lo largo de estos años una mejora sustancial de la calidad docente ${ }^{8}$. De forma progresiva se conseguía la anhelada meta de garantizar la formación especializada a todos los licenciados.

Es en la primavera de 2006 cuando, por primera vez, la Comisión Nacional de Recursos Humanos del Sistema Nacional de Salud se dirige al Consejo de Coordinación Universitaria, reclamando un aumento en el número de plazas de nuevo acceso. Ante esta solicitud, los decanos asumieron un incremento en todas las facultades españolas del 5\%, aunque la realidad fue que el incremento promedio fue del $9 \%$, que varió desde un $50 \%$ en la facultad de medicina de Las Palmas a un $5 \%$ en aquéllas que no lo habían solicitado. La Conferencia Nacional de Decanos (CND) intentaba mostrar así su disponibilidad a colaborar con la Administración y responder a las demandas sociales, aunque éstas no tuvieran base científica constatada. Insistentemente se defendía que cualquier incremento debería basarse, de una parte, en la realización de un estudio de necesidades acompañado de un registro de profesionales, $y$, de otra, en una mejora de los recursos de los centros a fin de mantener la calidad de formación. Sorprendentemente, a fecha de hoy, ninguna de las dos premisas se ha cumplido, más allá de las negociaciones y facilidades que algunos rectores han realizado con sus propias facultades.

El único estudio asumido por la Administración ha sido el de la excelente economista canaria Beatriz González López-Valcárcel, que indica, consideradas las próximas jubilaciones, la necesidad de proveer al sistema con 7.085 nuevos médicos a partir de 2016. Esto ha dado lugar a la conocida propuesta del Ministerio de Educación -ahora Ciencia e Innovación- de incrementar en un $40 \%$ las plazas ofertadas a lo largo de los próxi-

\footnotetext{
7. Véase el Libro Blanco de la Titulación de Medicina. La creación de la Facultad de San Pablo CEU no supuso incremento, dado que compartía dichos alumnos con la Universidad Complutense.

8. En cualquier caso, hay que considerar que nuestro sistema de acceso a la formación especializada -examen MIR- ha facilitado el predominio de la enseñanza conceptual en la universidad, frente a la formación en habilidades, asumiéndose que esto era competencia de la formación especializada.
}

ties of Medicine in Spain had levelled out at around $4400^{7}$. If we look at the European standards, our country complied perfectly with the magic figure of 1 student for every 10000 inhabitants. In fact, maintaining the number of students has made it possible to introduce substantial improvements in the quality of education over these years ${ }^{8}$. The coveted goal of ensuring specialised training for all graduates was gradually being accomplished.

It was in spring 2006 when the National Committee on Human Resources in the National Health System first addressed the University Coordination Council calling for an increase in the number of places for new admissions. In answer to this request, the Deans allowed an increase of 5\% in all the Spanish faculties, although in reality the average increase was $9 \%$, with a rise of $50 \%$ in the Faculty of Medicine of Las Palmas down to 5\% in those that had not requested the increase. In this way the CND (National Conference of Deans) tried to show itself willing to collaborate with the administration and to satisfy social demands, although they were not based on any proven scientific foundation. They insisted on defending the idea that any increment should be based, on the one hand, on a needs study accompanied by a register of professionals and, on the other, on improved resources for the centres so as to be able to maintain the quality of education. Surprisingly, today neither of these two premises has been satisfied beyond the negotiations and facilities that some Chancellors have carried out within their own faculties.

The only study conducted by the Administration was the one carried out by the excellent economist from the Canary Islands Beatriz González LópezValcárcel, who points out that, taking into account forthcoming retirements, as of the year 2016 the system will need 7085 new physicians. This led to the well-known proposal from the Ministry of Education (now Science and Innovation) to increase the number of places on offer by $40 \%$ over the next 5 years. Nevertheless, in the same study the author also warned of the difficulties that exist when it comes to planning in a market that is excessively segmented and has a high degree of mobility. The profession warned that the number of physicians in our country was

\footnotetext{
7 See the White Book on the Degree in Medicine. The creation of the Facultad de S. Pablo CEU did not represent any kind of increase because it shared its students with the Universidad Complutense.

8 In any case, it must borne in mind that our system of access to specialised training - the MIR exam - has facilitated the predominance of conceptual education at university, rather than training in skills, which was assumed to be part of specialised training.
} 
mos cinco años. Sin embargo, también se advertía en dicho estudio de las dificultades de planificación en un mercado segmentado en exceso y con gran movilidad. La profesión advirtió de que el número de médicos en nuestro país era superior a la media de la OCDE, que existía una mala distribución geográfica y déficit en especialidades muy concretas. Se preguntó por qué más del $40 \%$ de los profesionales colegiados no trabajaba en el sistema de salud; por qué todas las plazas acreditadas para la formación especializada no se ofertaban. Nada tuvo efecto. No se tomaron medidas a corto plazo para solucionar una demanda de hoy, pese a que los decanos planteamos que las decisiones sobre el acceso sólo tendrían efectos dentro de 12 años. Si el problema actual es cierto, ¿las medidas que se deben tomar son proveer de médicos para el 2020? ¿Cómo estará la sanidad en nuestro país entonces? Tampoco se asumió el tema de la calidad en la formación universitaria. Los rectores aceptaron una mayor oferta sin exigir, en general, contraprestaciones de ningún tipo. La suerte estaba echada, nuestros gestores, acostumbrados a nadar en la abundancia, no querían cambiar la agotada política de recursos humanos.

Poco antes de la Navidad de 2007-2008, lo que era presión política a las facultades de medicina existentes para incrementar el número de alumnos se transformó en decisiones firmes para la creación de nuevas facultades. El antecedente no podía ser más catastrófico en un país que asume que las leyes 'pueden' retorcerse para hacer 'legal' lo 'alegal'. La Universidad Católica San Vicente Mártir de Valencia, sin reunir los requisitos pertinentes, comienza a impartir el primer año de la titulación de medicina en $2007^{9}$. Sin embargo, es el Gobierno catalán quien propone en primer lugar la creación de tres nuevas facultades, Girona y Pompeu Fabra de carácter público, e Internacional de Cataluña de carácter privado, con un total de 220 nuevos alumnos. De nada sirven los esfuerzos de los decanos, los estudiantes de medicina, la Organización Médica Colegial, la Federación de Asociaciones Científico-Médicas de España o el propio sindicato médico, para ordenar la toma de decisiones. Poco después de Navidad, el Gobierno de la Comunidad Autónoma de Madrid, tras comprobar con los decanos madrileños

\footnotetext{
9. Sólo ante la presión de la CND, se reconvertirá a un título propio, pero con la esperanza de que sus alumnos no pierdan el curso en una próxima verificación del título, que de momento no se ha producido.
}

higher than the OECD average, that they were badly distributed, geographically speaking, and that there were shortages in particular specialities. The question was raised as to why over $40 \%$ of professionals registered in official associations did not work in the health system. And why some of the places accredited for specialised training were not on offer. All to no avail. No steps were taken in the short term to solve today's demand, although the Deans pointed out that the effects of the decisions concerning admission would only been noted in 12 years' time. If the current problem is true, then is providing physicians for the year 2020 the right step to be taken? What will our health care system be like then? The subject of quality in university education was not addressed either. The Chancellors agreed to offer more places, generally without demanding anything in return. The die was cast; our administrators, who were used to living a life of luxury, did not want to change the worn out human resources policy.

Just before Christmas 2007-08, what had been political pressure on the existing Faculties of Medicine to increase the number of students, became firm decisions to set up new Faculties. The decision could not be more catastrophic in a country that willingly accepts that laws 'can be twisted' to change what was 'illegal' into something 'legal'. Without satisfying the corresponding requirements, the Universidad Católica S. Vicente Mártir de Valencia began to teach the first year of the Degree in Medicine course in 2007 9 . The Catalan regional government, however, was the first to propose the creation of three new faculties - Gerona and Pompeu Fabra, which are public, and the Internacional de Cataluña, which is private - with a total of 220 new students. All the efforts of the Deans, medical students, the OMC (Spanish Organisation of Medical Associations), the FACME (Federation of Spanish Scientific-Medical Associations) or the Medical Trade Union itself had no effect on instilling some order into decision-making. A little after Christmas, following confirmation from the Deans in Madrid that it was physically impossible to admit twice as many new students, with a proposal for 880 new students, the regional government of the Autonomous Community of Madrid decided to promote the creation of four new faculties - Juan Carlos I, which is public, and

9 It was only under pressure from the CND that the degree course was reconverted into an Advanced Diploma ('titulo propio' in Spanish), but with the hope that its students will not waste a year when the qualification is confirmed some time in the future; to date this has not happened. 
la imposibilidad material de multiplicar por dos el número de alumnos de nuevo acceso con una propuesta de 880 nuevos estudiantes, decide fomentar la creación de cuatro nuevas facultades: Juan Carlos I, pública, y tres privadas concertadas con hospitales públicos, Alfonso X El Sabio, Francisco de Vitoria y Europea de Madrid. Una vez abierta la veda, son muchas las comunidades autónomas que plantean, poco después, la creación de nuevas facultades: Jaén, Almería, Baleares, Católica de Murcia, Castellón, Ciudad Real, Toledo, etc.

Esta nueva fiebre, de consecuencias inciertas, coincide con la apertura del plazo por parte de la Agencia Nacional de Evaluación de la Calidad y Acreditación para recibir propuestas de titulaciones adaptadas al espacio europeo de educación superior que deseen comenzar en 2009. A mitad del mes de febrero se presentan, para su verificación ${ }^{10}$, junto con la ya existente de Navarra, las propuestas de las universidades de Girona, Internacional de Cataluña, Pompeu Fabra -titulación compartida con la Universidad Autónoma de Barcelona-, Juan Carlos I, Europea de Madrid, Alfonso X El Sabio, Francisco de Vitoria, Católica de Valencia y Católica de Murcia. Sólo las cinco primeras se han aprobado. Sorprendentemente, nuestro sistema de verificación se realiza sólo según la documentación aportada por los proponentes. Nadie ha verificado la realidad ${ }^{11}$, al no contemplarse la evaluación externa ni la acreditación previa. Una vez aprobadas las titulaciones, se podrán evaluar tras seis años de actividad [sic]. ¿Se imagina alguien qué puede suceder? ¿Alguien puede creer, en nuestro país, que transcurridos seis años, con 1.000 alumnos matriculados, se podrá cerrar una titulación porque no cumplió lo prometido?

A mi juicio, la aparición de nuevas facultades en nuestro país es ya un proceso imparable. El que en esta ocasión algunas no hayan superado el listón burocrático del 'programa Verifica' no significa que no lo hagan en la próxima convocatoria. Es sólo cuestión de tiempo. Los que han rellenado los papeles de forma precipitada tendrán ahora más tiempo y lo harán mejor. Los que no lo

\footnotetext{
10. El programa Verifica de la Agencia Nacional de Evaluación de la Calidad y Acreditación evalúa las propuestas de los nuevos planes de estudio, valorando recursos, objetivos, sistemas de acceso, sistemas de garantías de calidad, calendario de implantación, etc.

11. El diccionario de la Real Academia Española define verificar como
} 'comprobar o examinar la verdad de algo'. three private state-assisted public hospitals: Alfonso X El Sabio, Francisco de Vitoria and Europea de Madrid. Now that the first step had been taken, there were many Autonomous Communities that shortly afterwards were to consider the idea of setting up new Faculties, for example, Jaén, Almería, Baleares, Católica de Murcia, Castellón, Ciudad Real, Toledo, and so forth.

This new fever, whose consequences remained to be seen, coincided with the opening of the period set aside by ANECA for the submission of proposals for degrees and courses that meet the requirements of the European Higher Education Area and seek authorisation to start in 2009. By the middle of February the following universities submitted proposals for verification ${ }^{10}$ : Girona, Internacional de Cataluña, Pompeu-Fabra (qualification shared with the Universidad Autónoma de Barcelona), Juan Carlos I, Europea de Madrid, Alfonso X el Sabio, Francisco de Vitoria, Católica de Valencia and Católica de Murcia, in addition to the one already submitted by Navarra. Only the first five have been approved. Strange as it may seem, our system of verification only takes into account the documentary evidence provided by those putting forward the proposals. Nobody has verified the real situation ${ }^{11}$, since neither external assessment nor previous accreditation is considered. Once the degree programmes have been approved, they can be assessed after 6 years of activity [sic]. Has anyone an idea of what may happen? Can anyone believe that, in our country, after 6 years and with 1000 students registered in the courses, a degree course can be closed down because it doesn't fulfil the initial promises?

In my opinion the appearance of new Faculties in our country is already a process that cannot be stopped. The fact that this time some of them have not passed the bureaucratic test of the 'Verifica program' does not mean that they are not going to do so in the next call for applications. It's just a matter of time. Those that have rushed to fill in the forms will now have more time and will do it better. Those that have not done so will do it well. Our country will have between 42-45 centres, more than any other country in the world except Cuba, in terms of the number of Faculties of Medicine per inhabit-

10 The Verifica program developed by ANECA (National Agency for Quality Assessment and Accreditation) evaluates the proposals for new study programmes by assessing their resources, objectives, systems of access, quality assurance systems, implementation schedule, and so forth.

11 The Oxford dictionary defines 'verify' as: 'make sure or demonstrate that (something) is true, accurate, or justified.' 
han hecho lo harán bien. Nuestro país alcanzará los $42-45$ centros, superando a cualquier país, con la excepción de Cuba, en número de facultades de medicina por habitante. Ante este desorden, denunciado por la CND, el Gobierno y la Conferencia General de Política Universitaria ${ }^{12}$ han decidido posponer la decisión y nombrar una comisión de estudio sobre el número de alumnos de nuevo acceso para el curso 2008-09. Podrán existir numerosas facultades de medicina, pero parece deducirse que el número de alumnos para cada comunidad autónoma sí podrá quedar definido. ¡Ojalá ésta sea la decisión final! ${ }^{13}$ Así, a partir de ahora, cada autonomía reflexionaría sobre la rentabilidad de crear nuevas titulaciones. Creo que sólo la regulación a nivel nacional del número de alumnos de nuevo acceso, junto con la revisión anual de la oferta de plazas MIR, particularmente en las especialidades más deficitarias, puede evitar que el exceso de médicos de los años ochenta y noventa se reproduzca en nuestro país, generando de nuevo frustración y pérdida de confianza.

Por otra parte, la proliferación de facultades de medicina de carácter privado generará situaciones de desigualdad -económica- evidente en el acceso a los estudios claramente injustas e injustificadas. La utilización de hospitales o centros sanitarios públicos para la formación privada añade un plus de desigualdad social que no debería autorizarse ${ }^{14}$. Más aún si consideramos que el sistema de formación especializada es fundamentalmente de carácter público. Por otra parte, ¿saben los políticos que los alumnos de los nuevos centros, particularmente los privados, procederán de todo el territorio nacional y la Unión Europea? Nada que objetar si la formación fuera íntegramente privada. Este tema debería también considerarse en los futuros cambios que en el sistema de acceso a la titulación y a la formación MIR se produzcan.

No obstante, debe entenderse que si se han cumplido los requisitos legalmente establecidos en nuestra normativa, las nuevas titulaciones deben aceptarse sin titubeos. Sin embargo, anticipo problemas importantes en su desarrollo,

12. Regulada en el RD 546/2007, de 27 de abril, está constituida por los representantes de las comunidades autónomas y cinco miembros designados por el Ministerio.

13. A fecha de hoy, 17 de junio, se desconocen las decisiones de dicha comisión.

14. Resulta sorprendente que algunas comunidades autónomas hayan decidido derogar los convenios de hospitales públicos con universidades públicas para suscribirlos con universidades privadas. ant. Faced with such turmoil, which has been condemned by the National Conference of Deans, the Government and the General Conference on University Policy ${ }^{12}$ have decided to postpone the decision and appoint a committee to study the number of newly-admitted students in the academic year 2008-09. There may be a large number of Faculties of Medicine, but it seems likely that the number of students for each Autonomous Community will be set. Let's hope that this is the decision that is finally adopted! ${ }^{13}$ If this were the case, from now on, each autonomous community would consider the cost effectiveness of setting up new degree courses. I believe that the only way to prevent the surplus of doctors that occurred in the 80s and 90s from taking place again in our country (with all the accompanying frustration and lack of trust) is to regulate, on a national scale, the number of newly-admitted students and carry out annual reviews of the number of places available for MIR, particularly in the specialities with greater deficits.

On the other hand, the proliferation of private Faculties of Medicine will give rise to clearly unfair and unjustified situations of obvious (economic) inequality as regards access to the studies. The use of public hospitals or health centres for private training adds a little more social inequality to the situation and should not be authorised ${ }^{14}$. This is even more startling if we take into account the fact that specialised training is essentially a public system. Moreover, are politicians aware that the students in the new centres, especially the private ones, will come from all over the country and the EU? There would be no objections to this if the training were wholly private. This issue should also be considered in the future changes that may come about in the systems of admission to the degree courses and to MIR training.

It must be understood, however, that if the requirements legally set out in our laws and regulations have been complied with, then the new qualifications must be accepted without hesitation. Yet, I foresee important problems in their implementation which go beyond drawing up a

12 Regulated in the Royal Decree 546/2007, dated 27 April, this conference is made up of representatives from the Autonomous Communities and five members appointed by the Ministry.

13 Today, $17^{\text {th }}$ June, the decisions taken by this committee remain unknown.

14 It is surprising to note that some Autonomous Communities have decided to revoke the agreements between public hospitals and public universities and draw them up anew with private universities. 
que van más allá de la elaboración de un plan de estudios o la construcción de infraestructuras físicas adecuadas. La formación médica de calidad requiere no sólo la disponibilidad de profesorado debidamente capacitado, sino formalmente acreditado. Esta tarea no será fácil, particularmente en áreas en las que la elevada implicación asistencial dificulta la investigación. Para ello basta con consultar las bases de datos de la Comisión Nacional de la Actividad Investigadora. ¿Es posible autorizar la puesta en marcha de titulaciones sin profesorado?

Una tenue luz de esperanza veo, sin embargo, en este turbio panorama. La puesta en marcha de nuevas facultades, sin los condicionamientos de las estructuras tradicionales ya existentes, podría posibilitar la adopción de nuevas metodologías docentes, más innovadoras, y con una mayor posibilidad de convergencia europea. El trabajo en grupos pequeños, tutorizados, con docencia integrada y una temprana exposición a la realidad asistencial, que plantea la reforma de Bolonia, no casa bien con grupos masificados. Por otra parte, los necesarios cambios en el examen MIR, y la esperada puesta en marcha de la troncalidad, junto con una adecuada planificación de la oferta de plazas MIR, la elaboración del registro de especialistas y políticas de recuperación de profesionales 'inactivos', pueden eficazmente ajustar la demanda con la oferta en condiciones laborales dignas.

Nuestro país, por falta de planificación e intereses políticos miopes, está más cerca de perder una oportunidad clara de mejora de la formación médica, y del propio Sistema Nacional de Salud, que de incorporarse a las nuevas dinámicas de la universidad, vigentes en Europa y Estados Unidos. Es necesario un gran consenso nacional entre todas las instituciones implicadas. No obstante, visto lo visto, aunque reconozco cierto pesimismo, creo que los próximos meses serán, sin duda, apasionantes. De ello depende nuestro sistema de formación médica en los próximos 25 años. programme of studies or the construction of appropriate physical infrastructures. High quality medical training requires not only the presence of teaching staff with the right skills and abilities but also with formal qualifications and accreditation. This will be no easy matter, especially in areas in which the high degree of involvement in health care makes research more difficult. On this matter all we have to do is consult the National Committee on Research Activity (CNAI) databases. Is it possible to authorise the implementation of degree courses without teaching staff?

Nonetheless, I can see a faint glimmer of hope in this turbulent scenario. Setting up new Faculties, without the existing traditional conditioning factors, could allow new, more innovative teaching methods to be adopted that are more likely to be able to tie in with European convergence. Working in small groups supervised by a tutor with integrated teaching and early exposure to the reality of health care, as proposed in the Bologna Reform, is not compatible with oversized groups. Furthermore, the changes that need to be introduced into the MIR examination and the long-awaited introduction of mandatory core materials, together with suitable planning of the number of places to be offered in the MIR, the creation of a register of specialists, and policies designed to retrieve 'inactive' professionals can effectively adjust the demand to fit the supply in decent working conditions.

Due to a lack of planning and short-sighted political interests, our country is closer to missing a wonderful opportunity to enhance medical training and the actual national health system than it is to incorporating the new university dynamics that are to be found in Europe and the United States. Widespread national agreement between all the institutions involved is needed. But, in view of the above, although I acknowledge a certain degree of pessimism, I believe that the next few months are going to be really exciting. The way our system of medical training works over the next 25 years is going to depend on what happens now. 